Banks, I., and Pollard, T. (2014) Beyond recall: searching for the remains of a British secret weapon of World War I. Journal of Conflict Archaeology, 9 (3). pp. 119-155.

Copyright @ 2014 W.S. Maney \& Son Ltd

A copy can be downloaded for personal non-commercial research or study, without prior permission or charge

Content must not be changed in any way or reproduced in any format or medium without the formal permission of the copyright holder(s)

When referring to this work, full bibliographic details must be given

http://eprints.gla.ac.uk/102033

Deposited on: 30 January 2015

Enlighten - Research publications by members of the University of Glasgow http://eprints.gla.ac.uk 


\title{
Beyond Recall: Searching for the Remains of a British Secret Weapon of World War I
}

lain Banks \& Tony Pollard

Centre for Battlefield Archaeology, University of Glasgow, Scotland, UK

\begin{abstract}
This article discusses the development of the Livens Large Gallery Flame Projector, a massive British flamethrower that was used against German trenches in the Battle of the Somme in 1916. Built underground within saps below No Man's Land, this secret weapon was an attempt to use technology to break through German defences and reduce British casualties. The flame projector was the most effective flamethrower developed in WWI, but proved to be too inflexible and expensive to be used.
\end{abstract}

Keywords: Flame Projector, flamethrower, the Somme, Underground War, William Livens

\section{Introduction}

The First World War was as much a war of technology as it was a war between men, and throughout the war, attempts were made to break the stalemate of the trenches through the development of new techniques and weaponry (see for example Showalter, 2006; Müller, 2006). Some of the developments of the war are very well known: poison gas is a defining element of the Western Front (Haber, 1986), while aerial warfare came into its own for the first time. In the past few years, the work of Peter Barton and Jeremy Banning has started to focus attention on the Underground War (eg Barton, 2011), which was fought beneath the trenches, some of it just below the surface while other tunnel systems plunged over $30 \mathrm{~m}$ under the Western Front. The tunnels were dug for a range of reasons, some of which are discussed in other papers in this volume; the particular purpose of the tunnels that are the subject of this paper was the construction of an Allied secret weapon. In this case, it was the construction of a Livens Large Gallery Flame Projector, a truly horrific weapon designed to wipe out the German frontline.

\section{Flamethrowers in the First World War}

The Flame Projector was a British response to the German use of the flamethrower. The flamethrower was first patented by Richard Fiedler in Germany in 1901, and he was given funds by the German Oberste Heeresleitung (German Army High Command) to continue development of the machine; it was introduced to a special pioneer company in 1908 (Wictor, 2010). The machines were 
little used at the start of the war because of technical problems, but these were resolved during 1915. Flamethrowers were used with some success against the French initially, with British troops facing their first experience of flamethrower assault on July 30, 1915 at Hooge (ibid.). This was a resounding success for the Germans, with the inexperienced British troops abandoning their trenches in panic. Relatively few of the casualties were direct victims of the flames, the majority being shot as the flames flushed them out of the trenches. The result was not particularly longlasting as the British re-took the trenches over the next couple of days, but the success of the attack convinced both the British and the French that flamethrowers had great potential for breaking the stalemate of the trenches.

The German tactic for flamethrowers used them as part of a shock troop that went in ahead of the regular infantry; the flamethrower operators were supported by riflemen carrying grenades and pioneers with tools and charges for breaching wire entanglements and other defences. Germany found the flamethrower to be an effective weapon in trench warfare: Wictor notes 653 attacks by the German Pioneer flamethrower regiment with a success rate of around $82 \%$ (Wictor, op. cit.) At the same time, the Pioneer regiments took quite high casualties, which meant that there was a constant need for replacement troops. These casualties are perhaps unsurprising given the role of the flamethrower operators as shock troops in advance of the main assault. While supported by rifles and machine guns, they were naturally the first target of any returning fire from the Allied trenches.

Both Britain and France developed portable flamethrowers, although the French were far more enthusiastic about their version than the British. British High Command considered the machines were too limited because of the speed at which the fuel was used up (c. 20 seconds), and the portable flamethrowers were used infrequently. Instead, Britain tried to develop larger versions. A first, relatively unsuccessful form was a medium-sized flamethrower that could last for 20 seconds but which had a longer range ( $50 \mathrm{~m}$ as opposed to the previous $30 \mathrm{~m}$ ); however, it needed two people to operate it. A heavier version could cover $80 \mathrm{~m}$ and last for 50 seconds, but required a crew of eight men. Both versions were impractical in the trench warfare of the Western Front, and they were rarely used (Payne, 2008).

While most developments by the combatants focused on portable machines like the German examples, the British also developed a very different approach. The Royal Engineers displayed a certain degree of lateral thinking; rather than using shock troops who had to face the dangers of No Man's Land before being able to deploy their weapon, the R.E.'s Special Brigade Z Company conceived of a flamethrower that would attack by stealth, with the approach to the German trenches being made underground. The flamethrower to be used was on a completely different scale to any existing machine; it was $17 \mathrm{~m}$ long and weighed 2.5 tons. It required 200 men to bring the parts together to be assembled, and it was not designed to be mobile. Instead, it was designed to be built in a side gallery of a sap running under No Man's Land, emerging just short of the German trenches. This flamethrower was named the Livens Large Gallery Flame Projector, after its inventor William Livens.

\section{Capt William H. Livens, R. E.}


Captain William Howard Livens was a civil engineer who joined the Royal Engineers on the outbreak of war on 4 August 1914, initially being in the Signals Corps of the R.E. He returned to Chatham in early 1915 in charge of the signallers' motorcyclists, but while in Chatham, he decided to work on poison gas as the British Army tried to respond to the German use of chlorine gas on 22 April 1915. He carried out a number of experiments on his own account while there, and it was suggested to him that he should apply to join Brigadier Charles Foulkes' Special Brigade who were working on the use of gas. He transferred to the Special Brigade in August 1915, and was unusual amongst his peers as being an engineer rather than a chemist (Richter, 1992: 148-49). Livens was very driven in his work, with Foulkes describing him variously as a 'go-getter' and as someone 'with little use for factors of safety or correct official procedure' (Richter, 1992.: 150). Livens himself after the war explained his motivation as a desire to kill 1,100 Germans in revenge for the deaths on the RMS Lusitania $^{1}$. In addition to the general outrage at the sinking of what was considered to be a civilian target, Livens believed that his fiancée Elizabeth Price had been on the Lusitania when it sank; according to his account given during an interview in the Daily Graphic, she had been intending to travel on the ship and had told him in a letter that she would be doing so (Anon., 1921). Livens said that he had received the letter the day before the sinking, and had assumed that she was lost. He had made enquiries and been told that someone of her name had been booked onto the ship. Three days later, he found out that she was alive and was coming home on a different ship, but by that stage he had decided to avenge the dead of the Lusitania. Whether this was genuinely how he felt at the time or it was a post-war justification will never be known. What is clear is that Livens set about the task with great energy and initiative.

Following his work on the flame projector, Livens became best-known for his work on poison gas and specifically the delivery system. He invented the Livens Projector, which was a cheap form of trench mortar designed to be fired remotely by an electrical current. Livens knew that gas could be delivered far more effectively than it initially was. The two techniques used in 1914 and 1915 were cloud attacks and gas shells. Cloud attacks depended on the release of a large cloud of gas from tanks, which risked the gas drifting back onto the attackers since the release was just in front of their own lines, or even within the frontline trenches. Gas poured out of arrays of gas cylinders, and drifted across No Man's Land towards the enemy. A shift in the wind could spell disaster, pushing the gas back into the attackers' faces (which happened in the first British gas attack at Loos on 25 September 1915). If the wind picked up speed, it would disperse the effect of the gas cloud, and would push it beyond the target before it could have maximum impact. It was also more effective psychologically than militarily, as the defenders could see the cloud coming and could prepare for its arrival by donning gas masks. Gas shells were more accurate and it was less likely that the gas would blow back, but the shells each carried a very small amount of gas and were largely ineffectual. Livens' projector was a way of overcoming the problems of both methods. The Livens Projector was a 9.5 inch steel pipe that fired a thin-walled gas canister with a payload of 30 lbs of phosgene; because it was fire remotely, there was very little warning of the barrage (Palazzo, 2002: 103). He also ensured that the projectors were deployed in large numbers (being very cheap to manufacture), so that large amounts of gas could be delivered on target very reliably and from a safe distance. Livens later claimed that in 1916 alone his projectors had killed over 700 German soldiers (Anon, 1921), and was satisfied that he had indeed killed at least 1,100 German soldiers before the end of the war in fulfilling his declared intention. 
After the war, Livens retreated into a certain degree of obscurity, although he continued to invent. He took out a patent in 1924 for a small domestic dishwasher that was remarkably similar in features to modern versions (Livens, 1924), while in WWII, he worked for the Petroleum Warfare Department and invented another flame weapon, the flame fougasse. This was a buried 40 gallon drum of petrol with a small explosive charge at one end. The drum would be buried, with the other end exposed. When the charge blew, a jet of burning fuel would flare out across an area $10 \mathrm{~m}$ wide for roughly 3 $\mathrm{m}$ in distance. Another cheap solution, around 50,000 fougasses were deployed during the war, mainly in southern England but also in Scotland ${ }^{2}$.

\section{The Livens Large Gallery Flame Projector}

Livens began working on flamethrowers alongside his work on gas delivery systems, spurred on after seeing other attempts at flame projectors such as a machine invented by Captain Vincent from the Ministry of Munitions. He was given a grant of $£ 450$ to do so (Richter, 1992: 150), working through his father's company Ruston, Proctor \& Co Ltd of Lincoln. He was also given four of the gas sections from the Special Brigade, forming a new and independent $Z$ Company which Livens commanded. Livens was able to move from initial design drawings to frontline assembly in the space of around 25 weeks, beginning from a demonstration of Vincent's flame projector that he witnessed in December 1915; the Livens Large Gallery Flame Projector was ready to be deployed by late June 1916, just in time for the start of the Battle of the Somme on 1 July.

As has been stated above, the flame projector was designed to be built in a tunnel. This made use of the fact that the battlefield was a three-dimensional battlescape, where attacks came from below the ground as well as across the surface. No Man's Land had tunnels known as Russian saps to take men and materials towards the German trenches, but out of the line of fire. With a Russian sap, the tunnel ended very close to the surface and the head of the sap was covered with timber and brushwood. This would allow the troops to emerge quickly from the tunnel right beside the German trench, having not had to face the machine guns of the defenders. The saps were also used for mines, detonating under the German trenches, and they were the perfect location for Livens' new invention. Because of the size of the flame projector, however, it could not be built in a main sap because it would block the passage for the advancing troops. Instead, the flame projectors would be built in a side gallery, leaving the passage clear for the infantry. When firing, the pressure pushing the fuel mixture would push the head of the machine up through the roof of the tunnel; the fuel would be ignited as the pressurised flow burst out of the mouth of the head (known as the monitor), and then would spray the German trenches with a sheet of flame. It could fire over 175 gallons (800 litres) of fuel in a ten second burst with a range of over $100 \mathrm{ft}$ (Richter, 1992: 153), providing far more impact than the capability of a portable machine. The stream of fire was directed across a ninety degree traverse (Richter, 1992: 157); the range and traverse were far superior to any other flamethrower. As the projector was turned off, and the monitor fell back down the shaft, troops in the main sap would emerge from the tunnel and storm the trenches. Irrespective of whether the flame had incinerated any of the defenders, the blast of flame would at least have forced any defenders to cover.

The British Army was reasonably enthusiastic about the weapon and 34 were commissioned (though only five appear to have been delivered). The Russian High Command also took an interest in the 
flame projector, and the parts catalogue was printed bilingually in English and Russian. MajorGeneral Sir Charles Callwell, who was attached to the Ministry of Munitions in late 1916, gave an account of having attended a demonstration of a flame projector at Hatfield Park in Hertfordshire (Callwell, 1920: 270); this is likely to have been a demonstration of the Livens Large Gallery Flame Projector because Hatfield was one of the locations used by Livens' Z Company for training and experimenting (Richter, 1992: 151). He was personally unimpressed by the flame projector, and considered that the Russian preference for this machine over the Stokes mortar (which he favoured) was an indication of a Russian weakness in practicality. Undoubtedly, Callwell was right to be concerned that the Russians were concentrating on the wrong technology as there is no evidence that the 20 flame projectors allegedly sent to Russia were ever put into use.

The first five flame projectors were used on the Western Front, in the northern sector of the Somme for the first day's assault. Two were set up at Carnoy in Saps 7 and 10, a few kilometres to the northeast of Mametz, while two were intended to be built at Mametz, one in Sap 13 and the other in Sap 14. The Carnoy projectors were used successfully on 1 July 1916, although there is no detailed account of the effectiveness of the firing; they were then disassembled and moved to be used at Guillemont on 3 September 1916, and at High Wood on 8 September (Palazzo, 2000: 99). It should be noted that both sustained damage from shellfire and had to be repaired and re-installed (Richter, 1992: 156). The flame projectors were given lukewarm assessments for their contribution in these cases, and the flame projectors were mothballed for over a year. On the night of 26-27 October 1917, a flame projector was used at Dixmude in Belgium with mixed results, the last occasion that one of the flame projectors was used in battle (Richter, 1992: 157-58).

The Army's initial enthusiasm for the flame projector had entirely evaporated. The reason was that the flame projector had some serious flaws. One issue was that the flame projectors used a tremendous amount of fuel, so widespread use of flame projectors was limited by the strain that would put on fuel supplies for the front; to put it into a modern context, the 175 gallons of fuel burnt in a ten second firing would be enough to drive a family car from Glasgow to Buenos Aires. The projector itself was extremely cumbersome, and having fired on its target, would need to be disassembled and then re-assembled in a new location. While it was clearly possible to do so, as the Carnoy machines demonstrated, It was not a weapon that could be used at short notice or in response to changing circumstances; while the Western Front was largely static throughout the war, the lack of flexibility of the weapon did not encourage its adoption. Again, the machines were complex and highly engineered, which was not ideal for conditions underground. Enemy action could easily damage the projectors; the machine in Sap 13 at Mametz was too badly damaged by German shellfire on 28 June to be used on 1 July and it was never used, unlike the two at Carnoy, both of which were damaged in the preparation for the September 1915 firing. However, the most fundamental objection to the flame projectors was that the High Command did not consider that the flame projectors were sufficiently effective. The range of the flame projectors is not entirely clear, but contemporary accounts suggest that it was less than $100 \mathrm{~m}$. Callwell's account of the display he saw at Hatfield Park was particularly dismissive:

This was a pleasant outing, and the demonstration was interesting enough in itself; but the elaborate contrivance seemed to me totally unsuited to the conditions on the Russian front, because the flame was only projected eighty yards--one was quite comfortable a hundred and fifty yards straight in front of the projector--and the device was only adapted to 
conditions such as had existed in the Gallipoli Peninsula and as held good at a very few points on the Western Front, where the opposing trenches happened to be quite close together. As a matter of fact, the contrivance had been found of very little use when tried by us in the field (Callwell, 1920: 270).

Livens' account of the firing of the Carnoy projectors suggests that the flame reached the target trenches and beyond; an entry in the war diary of $18^{\text {th }}$ Division ( $1^{\text {st }}$ Brigade) describes their casualties in the area covered by the flame projectors as having been far lighter than elsewhere, while another entry describes having seen charred bodies in the German trenches (Richter, 1992: 155-56). Livens went to investigate the effects on 2 July, and his estimate of casualties was around 40 German troops killed by the flame; for the strategists, this was a poor return on the labour and manpower required to mount a flame projector attack. Livens also measured the scorching caused by the firing of the flame projectors at 87 yards and 94 yards $^{3}$. This is in keeping with the results achieved in 2011 by Royal Engineers with a modern version of a flame projector, constructed as part of this project; this test firing produced substantial scorching of the ground, just as Livens was able to measure in 1916.

\section{Sap 14}

The first of the flame projectors to arrive on the Western Front was the machine destined for Sap 14. This sap was located at the Montagne de Cappy to the west of Fricourt and Mametz (Fig. 1), at a point where the opposing front lines were very close together. There was a complex of tunnels, shafts and saps in this area, some going deep below the clay and into the underlying chalk while others, such as Sap 14 were closer to the surface. Sap 14 was excavated by 183 Tunnelling Company of the Royal Engineers, running out under the frontline trench into No Man's Land, where it took a sharp $30^{\circ}$ turn to the east directly towards the German front line. At the turn, a side gallery was constructed and this is likely to be the intended destination of the flame projector; how far out in No Man's Land this was located is unclear because the maps drawn by the tunnellers are not to scale. The parts of the flame projector were to be brought to Sap 14 along a communications trench known as $71^{\text {st }}$ Street, down the eastern of two inclines that gave access to the sap. The following is taken from the Special Brigade R.E.' war diary ${ }^{4}$.

The parts of the flame projector were taken by Lt. Bansall and a sub-section of Z Company from Bronfay Farm, near Bray, on 27 June 1916 on three 3-ton lorries towards the front line, leaving at c. $8 \mathrm{pm}$ in the evening; they were then transferred onto ten General Service wagons (horse-drawn wagons). The intention was to rendezvous with a carrying party of 200 men from the $20^{\text {th }}$ Infantry Brigade (Devonshires) at a place identified as Ludgate Circus at the rear of the trench system, but the road became impassable for the wagons towards the rear of Ludgate Circus and there was a delay before the party of Devonshires could find them at $11 \mathrm{pm}$. The parts were unloaded, and the mixed group of Devonshires and R.E. Z Company started to carry the parts forward. They will have passed the Company $\mathrm{HQ}$ on their way to $71^{\text {st }}$ Street, a narrow communications trench that led to the frontline, and which was where the eastern incline down to Sap 14 was located. The effort of moving the parts forward can be seen from the fact that the party were still in $71^{\text {st }}$ Street three hours later, when they encountered a party of R.E. pioneers. As this communications trench was little more than one metre wide, this encounter caused a degree of confusion and delay; the war diary described it 
as 'a collision'. While this log jam of men and equipment was working its way through, a German artillery barrage began (at 2 am on the morning of 28 June), so the men dropped their burdens and took shelter. During a lull in the bombardment at around $5.30 \mathrm{am}$, Bansall's sub-section came out to collect what were described as the 'most important parts' of the flame projector, to put them under cover in the 'shallow gallery' of Sap 14; this was the incline down to the sap itself.

The recovery operation continued for roughly 30 minutes (the war diary says that the R.E. worked exceedingly well), during which time several parts were taken underground. However, at roughly 6 am, the recovery operation was brought to a sudden end by a German artillery shell, which exploded close to the entrance of the incline. The war diary rather laconically states:

$6 \mathrm{am}$ : Heavy shell sealed up end of sap for length of 20 feet, burying vital parts of the flammenwerfer [flame projector] beyond recall (WO95/122: 5)

The diary notes that no casualties had been sustained, but clearly men were caught underground. The next entry in the war diary talks about the party being withdrawn through the deep gallery at noon. Given that the diary entry had described the parts as being beyond recall, this may indicate that the six hours between entries was filled with attempts to clear the collapse and recover the parts. Whatever the case, Bansall's sub-section emerged back at the surface and then withdrew to billets at Sailly-le-Sec. There is no indication in the war diary about the fate of the parts of the flame projector that had been dropped in the initial shelling and which had remained on the surface, but they must have been collected up and taken back to Sailly-le-Sec where Z Company were now based. $71^{\text {st }}$ Street was too busy a communications trench for it to remain blocked with the bulky parts of a defunct machine, so the parts are likely to have been removed that day. The parts of the flame projector that had been taken underground were now buried in the collapsed incline, where they were to remain for the rest of the war.

\section{The Recovery Project}

Livens Large Gallery Flame Projectors had little publicity during the war, and even less after the war. Although the Daily Graphic did a piece about William Livens in 1921 (op. cit.), that article was all about his work with the Livens Projector and gas. Livens' work on flamethrowers and flame projectors became an historical footnote until the publication of Donald Richter's Chemical Soldiers in 1992. Richter's book was about the history of the Special Brigade, and he devoted a chapter to the flame projector ("Livens and the Flammenwerfer", (Richter, 1992: 148-58). However, this did not result in much further interest, and subsequent publications that discuss Livens' work in WWI pass rapidly over his flamethrower work. In 2006, the author Peter Barton and his colleague Jeremy Banning came across accounts of the flame projector in the course of research for the book The Somme (Barton, 2011). Barton and Banning examined the range of trench maps and tunnelling maps for the area around Mametz relating to the period leading up to the start of the battle of the Somme on July 1, 1916 and were able to establish the likely location of Sap 14 on Montagne de Cappy. Having initiated discussion with the propriétaire, M. Duplan, and the rentier, Eric Delporte, Barton and Banning took their idea that the flame projector parts remained in the collapsed incline to TV production companies and to Glasgow University's Centre for Battlefield Archaeology. The result was a research project funded by Channel 4 (Time Team Special) and the Discovery Channel through 
the Canadian production company Cream Productions, with the archaeological work carried out under the direction of Dr Tony Pollard and the present author with the assistance of the Royal Engineers, students from the Centre for Battlefield Archaeology at the University of Glasgow and students from the University of Artois in Arras, France.

\section{Site Location}

The site is located at $2^{\circ} 43^{\prime} 48^{\prime \prime}$ East and $49^{\circ} 59^{\prime} 13^{\prime \prime} \mathrm{N}$ (fig 1), just below the top of a chalk ridge running east-west to the south of the village of Mametz, which lies between Albert and Péronne in Picardy, France. The site overlooks the D938 road and the Devonshire Cemetery, where 163 men (mainly of the Devonshires) were buried in a section of British trench at the end of the first day of the battle of the Somme. The landscape is part of the rolling countryside around the river Somme, which is $5 \mathrm{~km}$ to the south, and the dominant land use in the area is agriculture. To the north-west of the site location is a small wood that preserves sections of the German trench system; elsewhere, post-war reconstruction has filled in all traces of the trenches and there is no surface indication of where they originally lay.

Although the underlying solid geology consists of chalk, it is capped by a thick layer of very heavy clay which is very sticky when damp, and dries to a very hard surface when dry. The underlying chalk is friable and full of fractures, which made tunnelling difficult according to the accounts of participants in the mining effort. During the period of the fieldwork, the team encountered both wet and very dry conditions, providing an insight into the difficulties faced by both surface and subterranean soldiers during the war.

\section{Project Aims \& Objectives}

The initial aim of the project was to re-open Sap 14 to be able to see the sap that allowed British troops on the day to storm the German trenches without casualties, but also to be able to open the collapsed incline and recover the pieces of the flame projector. To achieve this, it would be necessary to relocate the sites of the entrance inclines (one at on the western side and two on the eastern, one of which was the replacement for the original incline destroyed by the shell). This required a combination of using trench maps, GPS technology and geophysical survey. If Sap 14 survived underground, the intention was to undertake a comprehensive survey of the interior using laser scanning of the interior of the tunnel. Recognising that both inclines might be impossible to enter, it was also envisaged that the tunnel might be accessed using a mechanical excavator to break in from the top. It was believed that the saps were at shallow depth and relatively near the surface.

In addition to the work on the sap, the excavation was intended to record the details of the trenches at this location to provide a context and a contrast for the subterranean work. The frontline trench was a priority, but so too was $71^{\text {st }}$ Street where the entrance to the eastern incline to Sap 14 was located, and $72^{\text {nd }}$ Street, where the western entrance lay. Finally, it was hoped that the shaft for Sap 11, a deep gallery that was part of the mining system rather than a Russian sap, could also be excavated. There was no intention of attempting to go into the shaft itself because of time and 
resource constraints, but it was considered a worthwhile target to examine the head of the shaft where winching gear and ventilation equipment might survive.

\section{Methodology}

Historical research was always a vital part of the project because of the richness of the archival records for the Western Front. Jeremy Banning and Peter Barton undertook a thorough trawl through the available documents in the National Archives at Kew, including private diaries, official war diaries, trench maps, mine plans, aerial photographs etc. The importance of the information provided by this material to the success of the operation cannot be over stated. The research was undertaken by Peter Barton and Jeremy Banning through the National Archives at Kew.

The rich mapping available for the location was particularly important. Not only were there a variety of detailed maps of the trenches and the underground saps and mine tunnels, but there was a sequence of these maps giving time depth to the information. Progress in tunnelling could be followed from 31 March 1916 to a final map drawn on 31 July 1916 when the fighting had moved away from the area. The detailed mapping also allowed location plotting, using GIS and GPS technology. Digitised trench maps now exist for the Western Front and, combined with aerial photographs, allow for the straightforward location of once substantial features which have left little or nothing in the way of a surface traces. The Linesman system has become a very popular way of locating battlefield elements amongst archaeologists, historians and tour guides, and the project offered an opportunity to evaluate the accuracy of the system through the exposure by excavation of the exact locations of the trenches. The Linesman system has two potential inhibitors to its accuracy: the accuracy of the GPS unit being used, and the accuracy of the original trench maps. The latter have always been assumed to be very accurate, and this project also provided an opportunity to see how accurate they were both spatially and in terms of how much detail they revealed.

Geophysical survey was an initial element of the fieldwork for the project. Until relatively recently, there had been little application of geophysical survey to the archaeology of the Western Front because it was assumed that the surveys would be largely ineffective. This was because the conditions of the Western Front are not ideal for geophysical survey. There are huge amounts of metal still in the soil, with ordnance, barbed wire and so forth, all of which could impair the results of magnetometer surveys. The soil conditions themselves, where there is a high clay content, are not conducive to either resistivity survey or to GPR survey; clay is particularly difficult for both techniques. However, geophysical surveys have been carried out successfully on the Western Front over the past decade. Peter Masters has produced really excellent results at Ploegsteert in Belgium (Masters \& Stichelbaut, 2009), while the present author has successfully used magnetometry, resistivity survey and GPR on a number of projects on the Western Front (e.g. Banks, 2006; Pollard, et al., 2007; Banks, 2008; Banks, this issue). In this case, the intention was to investigate the site through resistivity survey and magnetometer survey. The work was carried out by Bactec Ltd using a Caesium pump magnetometer and by the present author using a Geoscan RM15 resistivity meter and a Geoscan FM256 fluxgate gradiometer. The purpose of the surveys was threefold; the first objective was to locate and map the trenches from which the entrances to the saps originated. As the area of the eastern entrance in which the projector parts were abandoned was disturbed by a shell blast, this location was considered to be capable of detection through geophysical survey. The 
second objective was to locate the main sap gallery as it ran beneath No Man's Land, even although it was recognised that the success of this operation would depend on its depth below the surface. The final objective was to locate the deep mining in the area by detecting the head of the shaft for Sap 11.

Finally, the main element of the project would be an area excavation that would include the frontline trenches, $71^{\text {st }}$ Street and $72^{\text {nd }}$ Street communications trenches and the head of the shaft for Sap 11. Sappers from the Royal Engineers at Chatham would assist in the excavation, and would also undertake various extra tasks for the purposes of the TV programme. These included building a mock-up of the entrance to an incline, and building a modern version of a Livens Large Gallery Flame Projector at the Royal Engineer's base in Chatham.

\section{Geophysical Survey}

The geophysical surveys were carried out in March 2010, with Bactec's Caesium pump survey undertaken first (fig. 2). This revealed the line of the trenches, although there was little detail in the plotted anomalies. There was also an indication of a linear feature running north from the trenches, which was interpreted as being the line of the sap.

In late March 2010, the resistivity and gradiometer surveys were undertaken. The resistivity survey was limited to three grids over the sap entrance area because of technical problems with the equipment; the remaining grids were surveyed at the start of the excavation phase, before the excavation trenches were opened. The first set of results were extremely good, although the results of the later grids were less clear than the first set because of the different conditions between March and May. In March, the ground was damp and it was raining for much of the survey period. By May, there had been very little rain for some time and the ground had dried considerably. As a result, there is a clear difference in the quality of the results from the two phases of excavation. Nonetheless, the results indicated the trenches very clearly, together with the location of the shellhole (fig. 3).

The range of data was extremely small (between 1.77 and 16.775 ohms, which is extremely low even for clay), and it was initially a surprise that any usable results had been recorded. However, the plot clearly shows linear anomalies that corresponded to the locations of the trenches. What was not appreciated until the excavation was quite how well the resistivity survey had detected the trench system. Because some of the anomalies were much stronger on the plot than others (although there was little actual difference because of the overall low range of readings), it was not immediately apparent that the anomalies matched the layout of the trenches recorded in the R.E. plans of the tunnels (fig. 4). In particular, $71^{\text {st }}$ Street can be seen to run on a curve as it crosses the survey area (bottom left of plot), which was matched on the R.E. maps and on the ground with the excavation. The two entrances to the eastern incline can be seen running east from $71^{\text {st }}$ Street, with the more northerly of the two running into an area of low resistance that appears as a patch of blue on the plot. This is the entrance to the incline that was collapsed by the German shell, the disturbance from which caused the lower resistance. 
The gradiometer survey (fig. 5) covered the area of the sap entrances and the British trenches as far as the entrance to Sap 11, a total of 15 grids. The results gave a greater level of definition to the trench system than the Bactec survey, allowing details of the different trench lines to be seen: these include forward and secondary lines of trenches, some suggestion of communication trenches and the end of $71^{\text {st }}$ Street which runs south away from the front line.

The survey also showed the same apparent linear feature as the Bactec survey, which seemed to emphasise that the interpretation was correct and that it represented Sap 14. It seemed remarkably unlikely, given the regularity and the length of the line of anomalies, that this could be a coincidence of anomalies and not a real feature. This apparent line also suggested that the origin of the signals was likely to be reasonably shallow for the gradiometer to detect it. However, excavation subsequently demonstrated that this was indeed merely a coincidence of anomalies, with one of the strong signals proving to be a dump of German shells and another to be barbed wire. The fact that the anomalies were spread out in a straight line running for roughly $35 \mathrm{~m}$ across the survey area makes the incorrect interpretation understandable, and emphasises that in geophysical survey, random factors can never be ruled out.

The magnetic survey also revealed details relating to the entrance area. Adjacent to the eastern part of the trench anomaly, there is a large area of high and low magnetic readings in a roughly rectilinear shape. This is in keeping with a shell crater and appears to match the low resistance anomaly interpreted as the shellhole. There was no obvious indication of an entrance or incline to the sap in the magnetic data, but this was less likely to be apparent than in the resistivity data.

There is an anomaly in the western end of the plots (towards top of fig. 5) that appears to be roughly rectangular, and is a very strong anomaly. This was in the right location to be the entrance of Sap 11 (shafthead), and it was interpreted as being evidence for the shaft. The assumption was that the chamber at the shaft head had been covered by an elephant shelter, and it was the metal from this that was causing the anomaly. The excavation did indeed locate the head of Shaft 11, but in a slightly different location. It must be assumed that the anomaly detected here was caused by some of the extensive amounts of metalwork lying in the ground.

There were a large number of very strong signals in the gradiometer survey, which matched the results of the Bactec Caesium pump survey. What this emphasised was that considerable care was required during the excavation because there was a high probability of encountering unexploded ordnance. Such material poses a major health and safety risk, and a protocol for dealing with such dangerous materials was put in place.

\section{The Excavation}

The excavation consisted of two separate areas of excavation adjacent to one another, and both within the area covered by the geophysical surveys (above). The main area of activity was a large trench of $40 \mathrm{~m}$ by $20 \mathrm{~m}$ covering the area of the inclines and the front line (fig. 6), with a trench of roughly $10 \mathrm{~m}$ by $10 \mathrm{~m}$ over the area of Shaft 11 to the west of the first trench. 


\section{Main Trench}

The main trench covered $71^{\text {st }}$ Street, $72^{\text {nd }}$ Street, the front line trench system and the western and eastern inclines to Sap 14. Because of the size and complexity of the main excavation trench, it was divided into sections: North West (NW), North Central (NC), North East (NE), South West (SW), South Central (SC) and South East (SE). Within the excavation trench, one set of sondages (small excavation trenches) targeted the surface features while another set targeted the inclines, aimed at locating entrances into the underground system.

\section{Gateway to the Underground: the Inclines}

The first attempt to access Sap 14 concentrated on the western incline, which had survived the bombardment undamaged. Once the topsoil had been stripped within the large excavation trench, the course of several trenches could be seen through the presence of patches of chalk within the clay. This was material that had been used to backfill the trenches after the end of the war, and was originally spoil from the mining operations from Sap 11 and the other deep mining tunnels. One of these trenches, located in the NW sector, appeared to match the R.E. plans where a side trench can be seen parallel to $72^{\text {nd }}$ Street and ending at the start of an incline. An indication of how this might have looked can be seen in a modern recreation of an incline entrance built by 36 Training Squadron, R.E. can be seen in the adjacent photograph (fig. 7). However, excavation indicated that there was no entrance from this trench into the incline. It was clear that, whatever the indication on the R.E. plan, either the trench had not contained an entrance and the plan was therefore wrong, or nothing survived of the entrance.

The R.E. map was reassessed, and the probable line of the incline established on the ground; matching the map to surviving features was a challenge because the map is a simplification and not a record of all features. The original trenches at this location were created by the French, with the British abandoning some trenches and digging new ones as they took over the sector. The archaeology is therefore a palimpsest that is far more complicated than the map. Having reassessed the map, sondages were then opened on what seemed to be the line of the western incline. These were machine-dug, initially with a mini-digger but as the excavation trench went down to a depth of c 4 m, latterly with a 360 excavator. The large excavation finally revealed the western incline, but it was a massive disappointment. Rather than a surviving tunnel running steeply down to the chamber of Sap 14, it proved to be a narrow feature running at a downward angle to the east, entirely filled with clay and very difficult to distinguish from the natural subsoil (fig. 8). All of the boards that had shored up the incline had been removed, and the clay had subsequently collapsed entirely within the incline. It was very clear that there was no prospect of gaining entry to the underground system through this entrance.

The R.E. trench maps also showed the incline entrance to Shaft 11 as being in the same trench and quite near at hand; this incline ran westward towards Sap 11. This incline had suffered the same fate as the incline to Sap 14. There was no sign of the entrance into the incline from the trench, while further excavation demonstrated that the tunnel itself was similarly collapsed. That meant that two of the entrances to the underground system were collapsed beyond recovery and increased the prospect that Sap 14 might not be accessible. 
The next target was the eastern incline, which lay in SE sector. There were two possible ways in from the east: the collapsed incline (the condition of which was not clear from the War Diaries) and the reconstructed entrance through the shell hole.

As it transpired the first of these was encountered first. Cleaning of the exposed surface revealed the line of $71^{\text {st }}$ Street, which like the trench shown on the trench plan, had a distinct curve to it, with the entrance to the eastern incline running off from the western extremity of this kink (see below). As excavation started at this location, a substantial piece of timber was revealed set into the surface of the ground. It was clearly structural and was set at an angle. The excavation then began to uncover a large metal object, which proved to be a vital component of the flame projector, and thus indicated that the collapsed eastern entrance had been located.

The exposed flame projector part was soon identified, through reference to the maker's manual, to be part 271 , the gate valve, and part 280 , the delivery head (fig. 9). These pieces, which were already bolted together, formed the section that turned on the flow of the liquid to the nozzle and without them, the machine was inoperable. As testament to the high quality of the manufacturing, despite having been in the soil for 94 years, the wheel operating the valve still turned smoothly at first attempt. This section of the projector was sitting on what appeared to be a step at the top of the incline and therefore was only just inside the entrance. It seems likely therefore that this section was dropped as the shell exploded and the incline was destroyed; the carrier may have done so accidentally or having recognised that the other important parts were now beyond recovery.

Just outside the incline, in the bottom of the $71^{\text {st }}$ Street trench, a set of tools and clamps from the flame projector were also recovered (fig. 10). These lay immediately below a series of eyelets and some leather fragments which represented the bag in which these parts were being carried. These were again likely to have been dropped in the aftermath of the shell's explosion. Despite extensive excavation in this area, which exposed much of the damaged incline and the area of trench with which it was joined, no further projector parts were recovered at this shallow depth.

As the excavation proceeded on the eastern incline, wooden boards were discovered running downwards at a steep angle to the west (fig. 11). This proved beyond doubt that the feature was the eastern incline and also that the shell had destroyed the feature. The wooden boards of the roof could be seen, but the walls had been blown together by the concussion, leaving the roof slats overlying the walls. It was apparent that in places, especially at depth, the wood survived in very good condition, partly because the clay was wet and anaerobic and partly because it would have been impossible to salvage them after the collapse of the feature. It also gave considerable hope that there would be further sections of the flame projector sealed within the destroyed incline.

In order to fully expose the timbers of the incline, the large mechanical excavator was brought onto the western part of the site, where it had already established that the western incline had not survived because of the salvaging of timbers from within during the war. Excavation proceeded from both directions, manually from the surface to the east and mechanically to depth to the west. Using this method, the timbers of the incline were fully exposed down to the level of the subterranean ante-chamber to Sap 14. The shell blasted timbers looked like a twisting rollercoaster track sloping down into the earth (fig. 12). The clay was very wet at the lower levels, and unfortunately it was while the excavation was down at this depth that there was heavy rain, making it difficult to work. By contrast the upper levels were drier and the roof timbers not far below the ground surface began 
to dry up and flake not long after exposure. Every attempt was made to dampen these down but it was obvious that these timbers would not survive the process of excavation.

Nonetheless, it was possible to retrieve a further piece of the flame projector, a length of extension pipe, from this depth (fig. 13). According to the flame projector manual this is part number 166, which is 4' $6^{\prime \prime}(1.37 \mathrm{~m})$ long. What was very apparent, however, was that the chamber itself was no longer extant. The wood had again been scavenged and the chamber had then collapsed. It underlined the fact that the survival of the timbers in the eastern incline was due entirely to its damaged and collapsed condition. The entire western incline, the chamber at the end of the inclines and the sap itself had all been scavenged and with all the shoring timbers removed had subsequently collapsed.

This removal of timbers had also impacted upon what appears to have been the incline created after the shell destroyed the original eastern incline. The entrance to this took the form of a series of sandbags lying in a rectangular feature which ran off $71^{\text {st }}$ Street immediately to the south of the original incline entrance. On excavation, it was again apparent that the wood used to prop the sides and roof of the incline had been removed - a slight change in soil colour was the only indication that an incline had ever been present. No further evidence for this replacement incline was found in the trench which had been dug to expose the timbers of the destroyed incline. It was by now clear that the underground system was entirely inaccessible. It is perhaps ironic that the only part of the entrance system to survive was the area which had been damaged by shelling, thus preventing the salvage of timbers.

The extension pipe and the gate valve/delivery head were only parts of the Flame Projector to be recovered from the collapse; however, there was also a set of monitor clamps recovered (part 31) along with a couple of spanners (part 793) near the surface and immediately adjacent to the gate valve, and a length of rope (possibly part 146) from within the incline. Nothing else was recovered relating to the flame projector. However, it is likely that there are further parts still in the collapsed incline. The war diary talks of the R.E. collecting the most critical parts and starting to move them underground before the final collapse of the incline, and it is unlikely that this rather laconic account meant only the removal of the gate valve and a length of pipe. It would be surprising if the monitor head was not recovered since it was one of the most substantial pieces of the projector and critical to its ability to fire. It would have been possible to investigate the remains of the incline further to locate another parts of the flame projector that might be present, but time was too short to allow further excavation. It was clear that the chamber at the end of the inclines which led into Sap 14 was no longer extant, while any further excavation would destroy what was left of the incline. It was decided that the most ethical approach would be to backfill and leave the remains for the future.

\section{The Trench System}

The trench system was very complex, as suggested by the sketch map of 20 Brigade (fig. 14). This indicates that there was not simply a front line and a reserve line, but that the front line consisted of at least three different trenches that intersected at different points and which also were connected through communication trenches such as $71^{\text {st }}$ Street and $72^{\text {nd }}$ Street. There were a series of 'traffic islands' within this complex, all of which made it difficult to see clearly as the topsoil was removed. 
The added problem was that, while $72^{\text {nd }}$ Street in particular had a lot of chalk in the backfill (making it very visible in the clay subsoil), not all of the trenches had chalk infill and instead were backfilled with a clay subsoil and thus very difficult to see. The presence of the chalk in the backfill was initially assumed to be an indication that the trenches were partially cut into chalk. However, excavation demonstrated that all of the trenches were entirely within clay; excavations of the inclines (see above) demonstrated that there was at least $4 \mathrm{~m}$ of clay overlying the chalk at this point on the hillside. The chalk is likely to have come from the deeper excavations to the west, relating to Shaft 11 and the other mining shafts; it was noticeable that there was more chalk used in the backfill of the western sector than in the eastern. The backfill of $72^{\text {nd }}$ Street was almost entirely chalk, whereas $71^{\text {st }}$ Street had relatively small amounts of chalk.

One of the factors contributing to the complexity of the trench system was the fact that there were two distinct phases to the history of the system. This area of the frontline was initially dug by French troops, who held the area from 1914 to 1915 . The trenches were then taken over by the British in the second half of 1915 and occupied until 1 July 1916 and the start of the Battle of the Somme, at which point the front line advanced into German-held territory. When the British took over this section of the front, they undertook considerable re-modelling of the trench; some of features were infilled, while others were re-cut to reduce the width and deepen them. In some cases, new trenches were dug to replace the French trenches. In other cases, there are references in war diaries to this being done because of the unhygienic nature of trenches that had been occupied for over a year already, and this may have been the motive here. In addition, there was a constant need to repair damage caused by German bombardment, only one element of which was the construction of a second eastern incline to Sap 14 after the original was destroyed.

\section{Communications Trenches}

At its most basic, a communication trench is a fairly simple feature serving a primary function of moving men between the front line and reserve trenches. Consequently, they do not require the same features as fighting trenches such as parapets or firing steps. Instead, they tend to be narrow slots designed to provide cover from bullets and shrapnel. However, even a trench with a simple purpose could become more complex as changing circumstances required adaptation, as can be seen with the German communications trench at Mont St Quentin further east beside Péronne (Pollard, this volume). At Mametz, it became very clear that $71^{\text {st }}$ and $72^{\text {nd }}$ Streets were complex features, not least because of the number of other trenches and other features joining with them.

\section{$71^{\text {st }}$ Street}

This communications trench was a relatively straight feature running from Albert Street at the Company HQ forward to the frontline, crossing the reserve trench as it did so. This was the communications trench used by the party of Devonshires and R.E. on the night of 27/28 June 1916 . As it approached the frontline, the trench took a sinuous path curving to the west, back to the east and finally back slightly to the west as it joined the frontline trench (fig. 6). There were several features that joined $71^{\text {st }}$ Street: a few metres before the frontline trench, and as the trench was 
curving back towards the east, there was a junction with a secondary trench behind the frontline; at the fullest extent of the bulge towards the west were the two entrances to the eastern incline; on the eastern side of the trench, and further to the south, was a small rectangular feature (bomb store) joining the trench from a very short spur of trench.

The trench that formed $71^{\text {st }}$ Street was between $1.4 \mathrm{~m}$ and $1.2 \mathrm{~m}$ wide, narrowing to c. $0.5 \mathrm{~m}$ wide at the base of the trench, and survived to a depth of roughly $1.4 \mathrm{~m}$ (although there would have been greater depth provided by sandbags and upcast from the digging of the trench). There was no sign of duckboards in the base of the trench. This was the narrow passage where the Devonshire/R.E. party collided with a group of Pioneers; laden down with the bulky components of the flame projector and in the dark, it must have been complete confusion and chaos as the two groups struggled to get past one another.

\section{Bomb Store}

The small rectangular structure mentioned above as one of the features connecting with $71^{\text {st }}$ Street was a bomb store. A short stretch of access trench led to a square chamber measuring $2 \mathrm{~m}$ by $2 \mathrm{~m}$ and constructed from upright timber posts with walls made from piled sandbags (fig. 15); the chamber first appeared as a pattern of postholes. Excavation revealed a widening of the access trench at the chamber entrance which formed a small ante-chamber. The western wall of this antechamber, effectively the end wall of the access trench, was revetted by sandbags. Excavation of the chamber exposed a timber planked floor and the bases of walls formed by piled sand bags between the upright timber posts. This feature had presumably at one point had a roof but, like much of the timber below ground, this is likely to have been salvaged. The feature could not be fully investigated, however, because of the large amount of live munitions encountered during excavation. During the excavation, 35 chargers of .303 bullets were found along with 14 live hand grenades. The ammunition was reasonably unproblematic, but the hand grenades were a major concern, most of them lying on the floor against the northern wall and in the entrance area. Initially, the first few hand grenades were carefully removed for disposal by Déminage, but they continued to be uncovered. Health and safety required that the excavation of the feature be suspended and it was decided to cover with sandbags the unexcavated area where the grenades were appearing and then to backfill the feature. The secluded nature of this chamber, the heavy sand-bagging and the presence of hand grenades strongly suggests that this feature served as a bomb store - close enough to the front to be deployed rapidly for defence or attack and secluded enough for safe storage. It is also likely to have been one of the shelters used by the carrying party on the night of the loss of the eastern incline

\section{$72^{\text {nd }}$ Street}

At the opposite, western end of the trench was $72^{\text {nd }}$ Street. This trench was sectioned in two places and proved to survive to a depth of c $1.2 \mathrm{~m}$; the width was $1.3 \mathrm{~m}$ at the top and c $0.5 \mathrm{~m}$ at the base. This communications trench was a shorter feature that began in the reserve trench that crossed $71^{\text {st }}$ Street, and which also had an unnamed side trench coming off its eastern side that can be seen on 
the 20 Brigade map (fig. 14). $72^{\text {nd }}$ Street is depicted differently on the 20 Brigade map from its appearance on the R.E. map of the underground features; on the R.E. map, it runs at a diagonal angle towards the frontline, then takes a sudden bend westwards to run parallel with the frontline for a few metres and then turning back towards the frontline. On the 20 Brigade sketch map, it is shown as being much straighter lines. The unnamed side trench appears on both maps as well, but on the R.E. map, it is clear that this was the trench that contained the entrance to the western incline. This appeared in the excavation trench as a length of trench that ran roughly parallel with the front line, but which terminated in a T-junction. It was within this feature that the remains of the robbed out entrance to the western incline and the slight traces of the incline itself were identified.

$72^{\text {nd }}$ Street also intersected with a narrower trench running roughly east-west (relative to site north), the intersection coming near the point at which the R.E. map shows $72^{\text {nd }}$ Street taking a sharp bend. Unfortunately, it was not possible to excavate the narrower feature or to investigate the relationship between the two trenches, so it is not known whether they connected or whether one cut the other. This trench ran roughly parallel with the front line. It was roughly $1 \mathrm{~m}$ wide at the surface, narrower than $72^{\text {nd }}$ Street. It led to a sheet of corrugated iron that overlay a timber frame; initially, it was believed that this was a possible entrance to the western incline. However, the timber frame did not connect to any subterranean features and was in the wrong location for an entrance to the incline. There are two possible interpretations, although both assume that the trench was an earlier comms trench dug by the French in 1914-15. One possibility is that this length of trench was the element of $72^{\text {nd }}$ Street that is shown running parallel with the frontline in the R.E. map, and that the British reused it when digging $72^{\text {nd }}$ Street. In that case, the frame and corrugated iron could have been part of blocking off the remaining section of comms trench running to the east beyond $72^{\text {nd }}$ Street. The second interpretation is that this trench was filled in by the British when they took over the sector and $72^{\text {nd }}$ Street continued on the other side of the feature. If there was a further length of $72^{\text {nd }}$ Street beyond this comms trench, it was not visible on the surface, and there was little space before the frontline for $72^{\text {nd }}$ Street to cut back and run parallel with the frontline. It seems most likely, therefore, that the French comms trench was re-used as part of $72^{\text {nd }}$ Street.

There was a further section of narrow trench to the east of this French comms trench, though this was narrower still. However, it was on the same alignment and was probably a continuation of it. If this is the case, and again time constraints meant that this possibility could not be fully explored, then the trench narrows from $1 \mathrm{~m}$ to $0.6 \mathrm{~m}$ at its terminus. The terminus was definite and had been dug on the square. The fill included large amounts of chalk, and at the terminal end was just over 0.5 $\mathrm{m}$ deep. The trench was cut by a sub-circular feature on the northern side, probably a shellhole, which contained various pieces of French military kit; two rucksacks with blanket rolls attached, and a French épée bayonet were particularly striking (fig. 16). It was initially believed that these were items left by the French troops when they ceded the trenches to the British. On reflection, however, it is very unlikely that material like this would have been left lying around in the British-held trenches until after the end of the war, so these pieces of kit could be assumed to have been deposited in the shellhole and the feature backfilled during the war, and probably before July 1916 . This interpretation is supported by the subsequent discovery during excavation of this area as part of the exposure of the eastern incline, two sets of human remains were found lying next to each other (see below). These bodies, buried in a shallow grave, lay immediately adjacent to the shellhole with the two backpacks, so there is a possibility that they are all associated and that the backpacks were the personal effects of these two victims of the fighting. 
The Burials

Two sets of human remains were encountered in a shallow grave in close proximity to the shell hole containing the knapsacks and other French equipment (fig. 16). The remains were encountered during the stripping of soil layers during the attempt to locate the western incline to Sap 14. Both sets were incomplete, with only the leg bones, feet and the left arm and skull of one individual surviving. It was apparent that the shallow grave had been disturbed by on site activity at some point during the war, probably when the trench complex was being modified by the British. A shrapnel ball and the shattered condition of some of the bones suggests that these men were killed by a German shrapnel shell - which may also in part have been responsible for the incomplete nature of the remains.

Remnants of blue and black fabric survived, which immediately suggested that the soldiers were French. This impression was confirmed when several tunic buttons bearing French insignia were recovered from the grave fill. The buttons associated with the western-most set of remains bore a standard flaming grenade motif which is indicative of the regular French army. The eastern-most remains, however, were associated with buttons bearing an anchor and entwined rope motif. This maritime image is associated with either marines or colonial troops from Africa. Given that there appear to be slight differences in the design of these buttons, the examples recovered seemed more likely to relate to a colonial soldier, probably from Morocco or another North African French colony. It is possible that these men were killed during the German offensive in December 1914. The remains of these two soldiers were handed over to the Commonwealth War Graves Commission, who passed them onto the French authorities for re-interment in a French military cemetery.

As previously discussed, the knapsacks and other French equipment found in the base of the nearby shell hole were first interpreted as kit abandoned by the French when the British took over this sector in 1915. It seems too much of a coincidence that two sets of French kit were dumped directly next to the graves of two French soldiers and that there was no connection. During the excavation and recording of the back packs, which had been emptied of their contents, it was noticed that the rolled blankets, which were attached to the top of the packs, bore the dish-like depression created by the backs of the heads of the men who wore them. This observation now seems all the more poignant given that the probable wearers were lying side-by-side very close-by.

The Frontline

The frontline was generally well-preserved. It was investigated through two sondages, which were very similar in nature, if not in content. In the first sondage, the cut contained a wall of sandbags at the front. These survived as stains of the decayed hessian (fig. 17), but were also more compacted that the remainder of the backfill; this made it possible to expose the sandbags, although as the dry weather dried out the soil it became much more difficult to maintain the structure of the sandbags. The sandbags were held in place by steel pickets. The second sondage was very similar, having the wall of sandbags at the front held in place by pickets, but in this case there was a second wall at the rear. The pickets in the first sondage were twisted and bent, while at this location there was a 
change in the sandbag wall with bags of chalk fragments appearing within a short section. This has been interpreted as damage from a shell burst, with the chalk bags acting as a repair. The base of the trench had duckboards still extant, consisting of a wooden beam, with smaller pieces of timber running perpendicular across the beam; in the second sondage, the duckboard was very similar. The trench had been deliberately backfilled, shown by the use of sandbags in the infill, which was probably done by local farmers after the war, at which time they were paid by the metre for filling in trenches.

There were a number of interesting finds within the frontline trench (fig. 18). These included a gas alarm made from a British shell case; a petrol can; a French épée bayonet; a large cache of fired cartridges that probably derived from a Vickers machine gun; and an early phase gas hood. There was also a small tin, probably for meat, which had been crushed and pushed in against one of the pickets holding up the front wall (see fig. 17). In the second sondage, there were steel drums dug into the ground on either side, filled with charcoal at the base. These probably represent homemade braziers used during the winter.

Joining with the front line was a secondary trench, which at its eastern terminus joined with $71^{\text {st }}$ Street. Once again this feature provided evidence for the modification and remodelling of the trenches over time, with the main changes probably occurring as the British took over from the French at this location. This trench was $1.9 \mathrm{~m}$ wide at the top, which made it wider than all of the other trenches with the exception of the frontline, which was over $2.5 \mathrm{~m}$ wide. A single sondage was cut through this trench to expose east and west facing sections, at a point not far to the east of the turn in the trench which took it northward to join with the front line trench. Intriguingly, the eastfacing section showed distinct evidence for an earlier trench, with straight northern side and flat bottom, being cut into to the rear, south, by a wider trench, again with a straight southern side and flat bottom. There was no sign of a re-cut in the west-facing section, though the northern edge of the trench was not exposed in the width of the sondage. The upper parts of the backfill in both sections consisted of chalk rubble, which could be seen as a distinct band on the surface prior to excavation. The uppermost fill, which sat within a void with steeply sloping sides so narrow that it almost appeared to be a feature cut down into the backfill, was a green sand, which may have originated as the fill of sandbags.

The earlier trench, visible in the east-facing section appeared to have been backfilled with a compact silty clay in a single episode. Whether this was as the result of a shell impact is uncertain - it seems a probable cause though no shell crater as such was visible. Limited damage from a shell may also explain why there was no evidence for re-cutting just over a metre further to the east (in the westfacing section).

Considerable amounts of material culture were recovered from the several sondages, including hundreds of cartridges (both .303 British and Lebel $8 \mathrm{~mm}$ ), chargers (clips of .303 ammunition), shrapnel balls, shrapnel, flare cartridges and shell nose caps. These all evoke the constant artillery barrages and rifle fire that would have been a part of life in the frontline before 1 July 1916, but there were hints of other experiences as well. There were the remains of shovels and pickaxes, the tools that would have been used to dig and maintain the trenches. There were food tins, a water canteen, mess tins and quite a few fragments of S.R.D. rum jars; there were also other alcohol bottles including a whisky bottle and a champagne bottle. Other glassware included two sauce 
bottles, an intact decanter and a Vaseline jar. The soldiers themselves were shown by buttons, pieces of watches, part of a pipe, the remains of a helmet and a lapel badge for the R.E.; this was a particularly poignant discovery with the presence of R.E. sappers on site throughout the excavation.

Shaft 11

This shaft was part of the deep mining system, separate from the saps that formed the shallow mining system. Although there was no intention to gain access to Shaft 11 it was hoped that the exposure of the shaft head, which was located to the west of Sap 14, would provide a further insight into the present condition of the subterranean features. It was apparent from the search for the western incline of Sap 14 and the total absence of any internal timbers that the timber lining of the subterranean features, which included Sap 14, had been removed for re-use elsewhere after July 1 , 1916. The fact that the timbers survived in situ in the badly damaged eastern incline to Sap 14 appeared to be the exception which proved this rule. However, any lingering doubts were removed on the exposure of the head of Shaft 11.

The top of Shaft 11 was visible as a roughly hexagonal patch of chalk-rich soil on the surface. Excavation revealed that the shaft went down in a rough cone at an angle of approximately $40^{\circ}$ on both the east and west sides for $2.4 \mathrm{~m}$. The shaft had been backfilled with soil containing a lot of chalk fragments and it stood out clearly in the section (fig. 19). The feature was excavated on the northern side, leaving the southern side unexcavated as a baulk. Because of the depth of excavation, it was necessary to do a box excavation to reduce the risk of the side walls of the trench collapsing; accordingly, the walls of the feature were preserved in section only. When excavation reached the level of the shaft head at $2.4 \mathrm{~m}$ below the modern ground surface, the exposed northern half of the feature was approximately 2 metres in diameter. It was entirely unclear how the shaft itself had been backfilled, whether the backfill extended down to the bottom of the shaft or just onto a timber or metal raft, and for this reason the feature was regarded as a serious health and safety risk. The level reached was the point at which there was a chamber adjacent to the shaft proper. This chamber was the pump room for the ventilation of Shaft 11, and disappearing into the northern side of the shaft was a degraded canvas hose with wire ribs. Cleaning back on the hose exposed a large set of bellows (fig. 20) which had been used to pump air into the shaft and the underground system. The bellows were constructed from timber and leather (the latter being highly degraded) and were of a type which may have originated in a smithy. Two heavy iron handles were located close by, and were clearly indicative of manual operation (this would be beneficial as the noise of an engine would have altered the Germans to tunnelling activities). From the presence of truncated timbers the bellows appears to have been accommodated in a semi subterranean structure concealed to the north of the shaft head. Unfortunately, the combination of time constraints and health and safety concerns meant that the excavation of this feature had to be abandoned. What was clear, however, was that although the bellows had been abandoned and left to decay in the ground, all of the timbers had been removed at a later date; there was no sign of the structural timbers of the pump room.

\section{Discussion}


As the introduction stated, the First World War was a conflict that stimulated considerable innovation in the technology of killing, with ever more effective ways of killing substantial numbers of people. William Livens was a key part of this innovation, finding different ways to improve weaponry. He was devastatingly effective with the Livens Projector, which delivered large quantities of gas into German trenches at a low cost that allowed its widespread adoption and use. He received a great number of plaudits for his invention, which was considered to be the most cost-effective weapon of the war (Haber, 1986: 120). His invention of the flame projector was far less successful, and while an engineering triumph, was a military failure. As a piece of engineering, the Livens Large Gallery Flame Projector was a triumph, clearly superior to all other flamethrowers and particularly of the rival Vincent flamethrower (Richter, 1992: 157). As a weapon, it was too unwieldy, requiring weeks of tunnelling to provide a location for the construction of the flame projector, which itself required a highly skilled crew to build and fire the weapon. While it could be disassembled and moved to a new location (as the Carnoy examples were, being moved to Guillemont and High Wood), the weapon was too inflexible for it to be an attractive option for High Command. Allied to this was the fact that, unlike the Livens Projector which killed Germans extremely cheaply, each firing of the glame projector was extremely expensive because it used so much fuel. It is also not clear how lethal the weapon was. The Carnoy shots appeared to have killed around 40 German soldiers (Richter, 1992: 155-56), while the High Wood shot was claimed to have knocked out a German machine gun. However, on this occasion, the report said that there were no burned bodies and it is not clear what the effect of the firing had been. Certainly, the various reports of the effectiveness of the machine all describe its usefulness as a weapon of terror that caused German troops to break. However, this was nowhere near as effective as the Livens Projector and it was only to be used once more, in October 1917.

The fate of the flame projectors following this last firing is unclear, but no examples were preserved and they survived only in a few photographs and the parts manual. The examples in Saps $7 \& 10$ were moved, last known in Dixmude in Belgium on the night of 26/27 October 1917. What happened to them afterwards is unknown. The flame projector in Sap 13 was abandoned, although parts were salvaged from it and it is likely that all the key parts were removed; however, the account states that the mechanism was wrecked by shellfire, so it is entirely possible that there are significant parts of the flame projector still in Sap 13 that were too badly damaged to be worth salvaging.

Clearly, the 2010 project has given the lie to the entry in the Special Brigade war diary that described vital parts of the Sap 14 flame projector being buried beyond recall. The excavation allowed some parts of the projector to be brought back to the light of day, with the remaining pieces also capable of recovery. Other parts of the projector are likely still to lie within the collapsed incline. The gate valve and attached delivery head were found close to the surface and only just within the incline, with the tools lying close by. The war diary is quite clear that the 'most important parts of Flammenwerfer collected and placed in $\mathrm{Sap}^{\prime 5}$; the extension pipe that was recovered does not really fulfil that description and it would be logical to assume that it was not the only piece to be carried into the incline. The pipe required four people to carry it because of the weight; if Bansall's section were recovering important parts of the machine that they knew well, the pipe would not have been their first target. It is likely that parts of the monitor will be in the incline, together with parts of the projection pipe that required various high specification valves (eg parts 336 or 493). These are likely to remain in the incline for future recovery; the caveat to this is that there would need to be a sound 
research question to justify further disturbance of the buried incline. Currently, it is a buried monument to the network of saps and inclines near the surface.

No longer beyond recall, the Livens Large Gallery Flame Projector is no longer a secret either, with the excavation having been the subject of a Channel 4 Time Team Special. Indeed, following on from the project, there was an exhibition on the flame projector at the Historial de la Grande Guerre in Péronne from June to December $2011^{6}$. However, the flame projector remains a little known part of the technology of warfare in the trenches, a fascinating insight into the inventiveness that contributed to the slaughter on the Western Front during the First World War. It is perhaps a blessing that the machine was not more effective. A massive sheet of flame suddenly bursting out from the ground with no warning is the stuff of nightmares, and we can be thankful that this particular weapon of terror was abandoned.

\section{Acknowledgements}

The Mametz project would not have been possible without the commitment, enthusiasm and cooperation of a large number of individuals and institutions. First and foremost, the project was the brain child of historian Peter Barton. Much of the detailed historical research was carried out by Peter's long term researcher and collaborator Jeremy Banning, who was an asset on site, proving to be a natural banksman for the machining of the site. The team from Bactec International provided essential information on the sub-surface character of the site and also provided invaluable safety advice. Gary Andrews provided invaluable practical support as the site manager, resolving issues of flooding, shoring and spoil management throughout the project. lain McHenry headed up site logistics and was busy organising facilities and equipment long before the project started. The sappers of the Royal Engineers were a vital part of the project and the excavation relied heavily upon their hard work and commitment (special thanks to Major Hazel Whiteman R.E. 36 Training Squadron, RSME, Chatham). Safety cover was provided by the Mines Rescue Company, who pitched in and assisted on a range of tasks with great enthusiasm; it is with regret that we note the passing of Adrian Scofield, who died shortly after the completion of the project.

The project also benefited from the assistance and cooperation of many of the people of Mametz and Péronne: in particular, M. Eric Delporte, the farmer whose land we excavated and whose company and good humour we so much enjoyed; M Stephane Brunel, the mayor of Mametz; François Bergez of the Historiale de la Grande Guerre in Péronne; Anthony Byledal and his friends who came to work on the site and were responsible for some of the most significant discoveries that were made; Centre Déminage Interdépartmentale de la Somme; Conseil Generale de la Somme; Préfecture de la Région Picardie; Jamart S.A.; Eiffage, Picardie S.A.;Clean Up S.A.;SARL GT LOC; M. Francois Boudot; M. Thierry Duplan; M. Alain Jacques of the Service Archéologue Municipale in Arras; Maggie Lindsay Roxburgh; Mairie de Ovillers-La Boisselle; The Royal Engineers Museum; Thierry and Marion Villain.

\section{Bibliography}

Anon., 1921. Story of Romance of a War Secret. The Daily Graphic, October 15. 
Banks, I., 2006. Resistivity Survey at Red Dragon Crater, Givenchy. Glasgow: GUARD report.

Banks, I., 2008. GPR Survey at Hooge Cemetery, Glasgow: GUARD report 12006.

Barton, P., 2011. The Somme: Unseen Panoramas. Rev ed. London: Constable.

Callwell, C. E., 1920. Experiences of a Dug-out, 1914-1918. London: Constable \& Company Ltd.

Haber, L. F., 1986. The Poisonous Cloud: Chemical Warfare in the First World War. Oxford: Oxford University Press.

Livens, W. H., 1924.Improvements in Apparatus for Washing Household Crockery and the like. FR579765. UK Intellectual Property Office. [online] [Accessed 24 June 2014]. Available at: < http://worldwide.espacenet.com/publicationDetails/biblio?CC=FR\&NR $=579765 \& \mathrm{KC}=\& \mathrm{FT}=\mathrm{E} \&$ locale $=$ en_EP>

Masters, P. \& Stichelbaut, B., 2009. From the Air to Beneath the Soil - Revealing and Mapping Great War Trenches at Ploegsteert (Comines-Warneton), Belgium. Archaeological Prospection, 16(4), pp. 279-85.

Müller, R.-D., 2006. Total War as a Result of New Weapons? The Use of Chemical Agents in World War I. In: R. \&. F. S. Chickering, ed. Great War, Total War, Combat and Mobilisation on the Western Front, 1914-1918. Cambridge: Cambridge University Press, pp. 95-113.

Palazzo, A., 2002. Seeking Victory on the Western Front: The British Army and Chemical Warfare. Lincoln, Nebraska: University of Nebraska Press.

Payne, D., 2008. Liquid Fire on the Western Front. The Great War on Land: Weapons, Equipment \& Uniforms [online] [accessed 24 June 2014]. Available at:

$<$ http://www.westernfrontassociation.com/great-war-on-land/weapons-equipment-uniform/270liquid-fire.html>

Pollard, T., Barton, P. \& Banks, I., 2007. Pheasant Wood, Fromelles: Evaluation of Possible Mass Graves, Glasgow: GUARD Report 12005.

Richter, D., 1992. Chemical Soldiers. Lawrence, Kansas: University Press of Kansas.

Showalter, D. E., 2006. Mass Warfare and the Impact of Technology. In: R. \&. F. S. Chickering, ed. Great War, Total War, Combat and Mobilisation on the Western Front. Cambridge: Cambridge University Press, pp. 73-94.

Watson, B., 2005. Atlantic Convoys and Nazi Raiders: The Deadly Voyage of HMS Jervis Bay. Santa Barbara: Praeger Publishers Inc.

Wictor, T., 2010. Flamethrower Troops of World War I: The Central and Allied Powers. Altglen, Pennsylvania: Schiffer Publishing. 


\footnotetext{
${ }^{1}$ The RMS Lusitania was sunk by a German U-Boat on 7 May 1915 with the loss of 1,159 civilians. There was outrage in Britain at the time over what seemed to be a war crime, although the Lusitania had been on a list of armed merchant cruisers and was listed in the 1914 Jane's All The World's Fighting Ships as an auxiliary cruiser (Watson, 2005: 9)

${ }^{2}$ WO $199 / 1433$

${ }^{3} \mathrm{~T} 173 / 702$

${ }^{4}$ WO95/122

${ }^{5}$ WO95/122

${ }^{6}$ Breathing Fire. Le Dragon de la Somme. Historial de la Grande Guerre, Château de Péronne, Péronne BP20063. 16 June - 16 December 2011.
} 